\title{
需要不確実性と流通チャンネル` 市場経済における中間業者の役割
}

\author{
酒 井泰 弘*，佐々木 啓 介*
}

\section{1.はじめに}

モノを「作る人」と「使う人」が存在する世界を考学る。そこにモノを「移動させる人」が 介在する根拠はどこにあるだろらか。この問いに答えるためには，「地域」や「空間」を考慮す ることが必要である。実際, もし地域や空間を無視すれば，輸送や情報収集の役割が消え，「中 間業者」の存在意義が薄くなるだろら。

現代の主流派の経済学においては，流通業者や中間業者が正面から取り扱われておらず，情 報と流通の関係が十分分析されてこなかった。ミクロ経済学のどの教科書を開けても，大活躍 するのは，生産者と消費者の 2 人だけで，中間業者が出る幕はほとんどない。ところが，現実 の経済をみると，モノが最初の製造業者から流れて最後の消費者に至るまでの間には，一連の 卸売業者や小売業者など，多数の流通業者が存在し活動している。本稿の狙いの 1 つ，この ような理論と現実の間のギャップを埋めることである。すなわち，本稿においては，地域経済 に和ける情報流通活動の観点から，中間業者の存在意義を明らかにしょらと試みる。

中間業者（卸売業者ないしは小売業者）の機能を考学ると，それは，(1) 集荷分散機能 (2) 流 通コスト削減の機能 (3) 需給調節機能 (4) 流通機能等に大別される。これらの機能は,「効率性」 という観点から説得力を持つ。特に最後の「流通機能」の具体的活動としては，（i ）商的流通 活動(販売，仕入れ，価格設定等)，（ii）物的流通活動(輸送，保管，配送等），（iii）情報流通 活動(情報収集，情報提供，情報管理等）があげられる。

上記の流通機能から（ii）の輸送・保管活動を捨象しても, 流通業者の存在根拠は残り得るの だろらか。この問題に対して，流通業の発生の歴史は興味深い示唆を与える。流通業の原初的 形態はそもそも「行商」であり，後に「店舗」として定着するようになった。彼らは生産者か

\footnotetext{
* 筑波大学社会科学系

†本論文は, 日本地域学会第 29 回年次大会 (1992 年 10 月, 専修大学) において報告したものを加筆修正し たものである。討論者の木村吉男教授 (中京大学) や松本昭夫教授 (新潟大学) をはじめ, M. ベックマン (ブラウン大学), 河野博忠 (筑波大学), 福地崇生 (京都大学), 太田浩 (青山学院大学) などの諸氏, 本 巻編集委員長の蔵下勝行氏 (専修大学), および 2 名のレフェリーから有益なコメントを頂いたことを記 し，厚く感謝申しあげたい。もちろん，ありうべき誤謬は，すべて筆者の責任である。
} 
ら消費者へ商品を運ぶだけではなく, 逆に消費者から生産者側へ需要動向を伝達していた。そ の場合には，消費者に直接対峙し「地の利」を持つ「行商人」や「店舗」は，生産者にとって も必要不可欠な存在になる。

現代社会に招いては，ファクシミリ，通信衛星，ビデオ，パソコン，情報誌などの発展と普 及にみられるように，人間生活の情報化が一段と進み，それが地域経済のワーキングに著しい 影響を及ぼしつつある。とくに，流通業に和いては，いわゆる「情報革命」が進行中で，地域 経済の内外において，情報システム化と情報ネットワーク化が盛んである。その中核となるの が POS システム（point of sales, 販売時点情報管理）である。POS システムによれば，単品別 に売上高が自動的に集計されるとともに，客筋に関する必要データ(性別，年齢，職業など)が 同時に処理される。これによって，地域経済の「売れ筋」や「死に筋」が的確に判断できるよ らになる。例㓪ば, つくばのよらな新興の学園都市では, 若者や研究者, 公務員の人口が急増 しているため，客筋が大幅に変化しつつある。このようなわけで情報流通活動の視点から中間 業者の役割を解明することは，情報革命が地域内取引に及ぼす効果を分析するための基礎を提 供するものと期待できよう ${ }^{1)}$ 。

中間業者の活動に関する従来の研究を見ると, それは産業組織論に㧍ける垂直統合の問題と して扱われることが多かった。例えば, Etgar [4], McGuire and Staelin [9], Coughlan [3] などの文献がある。しかし, 本稿は視点を変えて, 特に情報流通活動に焦点を当て, 中間業者 の存在根拠を分析してみようと思う。

流通業者の分析を行う際，寡占理論の道具立てを利用することができる。近年において，不 確実性の経済学の成果を導入して寡占理論は大きく発展した。その先駆的な論文として Bassar and Ho [2], Ponnsard [11]等があげられる。また，本稿ではレファレンス・ポイントとして， 丸山氏 [8] の先導一追随型流通系列モデルを取りあげるが，これは Sakai [13]による不確実性 下の先導一追随型モデルを基礎としている。さらに，関連する文献としては，Gal-Or [5]， Albaek [1], 酒井[14]等があげられる。丸山氏の分析では危険中立的販売者が仮定されていた が, 本稿では一歩進めて, 危険回避的販売者による販売系列も分析対象とする。危険回避行動 を仮定した論文としては Grossman and Stiglitz [6], Lim [7], Newbery and Stiglitz [10] な ぞがあり，それぞれ投機市場，金融業，貿易問題において有益な分析を試みている。寊占理論 の領域では危険回避行動の導入は少なく, Sakai and Yoshizumi [15], [16]によって試みられ ている。本稿では, これらの分析を流通問題に積極的に応用しょらと意図している。

本稿の内容は以下のと扤りである。第 2 節ではモデルの説明と販売者の役割が述べられ，第

1）流通業における情報通信の革新について，2名のレフェリーからいただいた御助言が大変参考になった。 重ねて感謝申しあげたい。 
3 節では情報構造が流通系列に与える影響が明らかにされる。第 4 節では, 危険回避的販売者を 仮定し，生産者への情報伝達について考察を加光る。最後の第 5 節では，本稿の結論と今後の 課題が述べられる。

\section{2. 生産者一販売者モデルについて}

本稿の関心は, 需要動向の情報を入手し, 生産者一消費者間に介在する販売者の存在にある。 とくに販売者の介在により生産者, 消費者が受ける影響, および販売者から生産者への情報伝 達などが考察対象となる。ただし，在庫や輸送の問題などは捨象する。

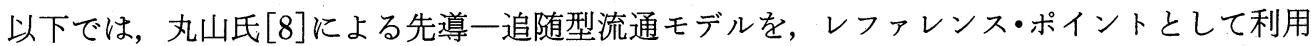
する。ここで想定する販売者とは, 生産者と消費者の間に位置する小売業者と考えてもよいし， 生産者と小売業者の間に位置する卸売業者と考えてもよい。生産者は, 市場の需要不確実性を 直接知りえないのに対して，販売者は，いわゆる「地の利」により，需要不確実性を知りらる と仮定する。追随者としての販売者は，生産者の提示する卸売価格を所与とし，生産者からの 仕入れ量を戦略変数として利潤最大化を図るものとする。これに対して, 生産者は先導者とし て，卸売価格を戦略変数とし，期待利潤の最大化を図る。したがって，このモデルは，不確実 性を伴うシュタッケルベルク寡占モデルに類似したものになる2)。

まず，無知の生産者が直接販売する場合を考えよう。このとき，期待利潤 $E\left[\pi_{P}\right]$ の最大化を 図る生産者の均衡産出量, つまり, 選択可能な産出量のなかで最大の期待利潤をもたらす産出 量 $x^{*}$ は, 次のように求められる。

$$
x^{*}=\arg \max _{x \geq 0} \underset{\tilde{\alpha}}{E}\left[\pi_{P}(x \mid \tilde{\alpha})\right]
$$

さて, 計算上の便宜のため, 確率変数 $\tilde{\alpha}$ を含む線形需要関数 $p=\tilde{\alpha}-\beta x$ を仮定し, 生産者の費 用関数を $C \equiv C x$ とする ${ }^{3)}$ 。また， $\beta=1$ と仮定しても，一般性を失わない。よって，生産者の期 待利潤関数は $E\left[\pi_{P}\right]=E[(\tilde{\alpha}-x-c) x]$ となり, 均衡産出量と均衡価格はそれぞれ $x^{*}=(E \tilde{\alpha}$ $-c) / 2, p^{*}=(2 \tilde{\alpha}-E \tilde{\alpha}+c) / 2$ として求められる。したがって, 生産者の期待均衡利潤は次式の ように定まる。

$$
E\left[\pi_{P}^{*}\right]=E\left(x^{*}\right)^{2}=(E \tilde{\alpha}-c)^{2} / 4
$$

2）本稿では, 生産者を先導者, 販売者を追随者と考えている。だが, 現代経済における商社やスーパーの活 動を見れば分かるように, 販売者のほうがリーダーの役割を演じるケースがある。この点の分析は今後の 課題である。

3）本稿では, 簡略化のため, 生産関数が線形だと想定している。固定資本が存在し, 収檴派減が作用する場 合には，モデル分析が非常に難しくなる。これからの研究課題であろう。 
消費者余剰を $\left(\tilde{\alpha}-p^{*}\right) x^{*} / 2$ で表すと $E\left[C S^{*}\right]=(E \tilde{\alpha}-c)^{2} / 8$ となり，余娂の総和 $E\left[\pi_{P}^{*}\right]$

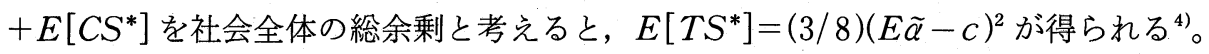

さて, 市場動向を把握する販売者が介在すると, 事態はどらなるであろらか。最初に, 販売 者が消費者の需要条件を生産者に伝達しない場合を考学る。いま, 販売者が決定する市場価格 を $p$, 生産者の産出量と卸売価格をそれぞれ $x, q$ で表し, 生産者の他の諸量には添え字 $P$, 販売者の諸量には $D$ を付ける(例えば $\pi_{D}$ は販売者の利潤を表す)。このとき，均衡産出量なら びに均衡卸売価格は次のように定式化される。

$$
\begin{aligned}
& x^{*}=\arg \max _{x \geq 0} \pi_{P}(q, x \mid \tilde{\alpha}) \equiv \phi\left(q^{*} \mid \tilde{\alpha}\right) \\
& q^{*}=\arg \max _{q \geq 0} \underset{\tilde{\alpha}}{E}\left[\pi_{p}(q, x(\tilde{\alpha}))\right]=\arg \max _{q \geq 0} \underset{\tilde{\alpha}}{E}\left[\pi_{P}(q, \phi(q \mid \tilde{\alpha}))\right]
\end{aligned}
$$

所与の卸売価格の下で, 販売者は, 各需要の実現値に対応した柔軟な購入量決定を行う。した がって, 販売者の利潤は $\pi_{P}=(p-q) x=(\tilde{\alpha}-x-q) x$ となる。このときの反応関数は, $\tilde{\alpha}$ に対 応した $x=(\tilde{\alpha}-q) / 2 \equiv \phi(q \mid \tilde{\alpha})$ として表される。無知の生産者は販売者の反応関数を期待値と して捉えるため, その期待利潤関数は $E\left[\pi_{P}\right]=(q-c) E[\phi(q \mid \tilde{\alpha})]$ となる。したがって, 以前と 同様に, 均衡卸売価格は確定值として $q^{*}=(E \widetilde{\alpha}+c) / 2$ と表される。ところが, 販売者の仕入れ 量は $x^{*}=(2 \tilde{\alpha}-E \tilde{\alpha}-c) / 4$ となるから，各均衡利潤は次のようになる5

$$
\begin{aligned}
& \pi_{D}^{*}=\left\{p^{*}-q^{*}\right\} x^{*}=(2 \tilde{\alpha}-E \tilde{\alpha}-c)^{2} / 16 \\
& \pi_{P}^{*}=\left(q^{*}-c\right) x^{*}=(E \tilde{\alpha}-c)(2 \tilde{\alpha}-E \tilde{\alpha}-c) / 8
\end{aligned}
$$

ただし，販売者の仕入れ量が確率変数であるために，生産者の利潤は確定値とはならない。生 産者と販売者の均衡利潤の総和は $E\left[P S^{*}\right]=\left\{3(E \tilde{\alpha}-c)^{2}+4 \operatorname{Var} \tilde{\alpha}\right\} / 16$ となり, 期待消費者余 剰 $E\left[C S^{*}\right]=\left\{(E \tilde{\alpha}-c)^{2}+4 \operatorname{Var} \tilde{\alpha}\right\} / 32$, 期待総 余剰 $E\left[T S^{*}\right]=\left\{7(E \tilde{\alpha}-c)^{2}+12 \operatorname{Var} \tilde{\alpha}\right\} / 32$ が 得られる。

以上に招いては，情報を入手している販売者が，その情報を生産者側に伝達しない場合につ いて，各均衡諸量を求めた。だが，当然のことながら，販売者が生産者と情報を共有する場合 も考学られる。次節では, 他の情報構造下での均衡諸量を導出し, 両者の場合を比較してみた い。

4）消費者余剰と生産者余㮃の総和としての総余鄱は，社会全体の厚生レベルを測るとみなしてょい。した がって，以下の分析に打いては，E[TS*] が増大するような市場組織が，社会的に望ましいものと考克 る。

5）ここでは，販売者サイドの費用面が無視されていることに注意されたい。 


\section{3. 流通チャンネルと情報構造について}

販売者一生産者間の情報構造が各利潤，各余㮃に与える影響を，以下で分析しょう。情報構 造としての (1) 販売者が無情報, 従って生産者も無情報の状態, (2) 販売者のみが情報を入手 し，生産者側に伝達しない場合（第 2 節では，この状態を調べたことになる)，(3) 販売者が生 産者側に需要動向を伝達する共有情報の状態, の 3 つの情報構造を考学る。

(1) 無知の販売者は, 生産者の卸売価格を所与として, 期待利潤最大化を目指し, 売れ残りが 出ないような仕入れ量を決定する。このとさ期待利潤関数は同様である。これより, 反応関数 は $x=(E \tilde{\alpha}-q) / 2 \equiv \phi(q)$ となり, 生産者の卸売価格に対し確定値として仕入れ量が決定され る。反応関数を考慮する生産者の利潤関数は, 確率変数を含まない関数として $\pi_{P}=(q-c) \phi(q)$ と表される。よって, 生産者は均衡卸売価格を $q^{*}=(E \tilde{\alpha}+c) / 2$ に定める。これを反応関数に代 入すれば, 販売者の仕入れ量 $x^{*}=(E \widetilde{\alpha}-c) / 4$ が得られ, さらに逆需要関数に代入する市場価格 $p^{*}=\tilde{\alpha}-E \tilde{\alpha} / 4$ が決定される。したがって, 販売者の均衡利潤は $\tilde{\alpha}$ の関数として, 生産者のそ れは確定值として次のように求められる。

$$
\begin{aligned}
& \pi_{D}^{*}=\left(p^{*}-q^{*}\right) x^{*}=(4 \tilde{\alpha}-3 E \tilde{\alpha}-c)(E \tilde{\alpha}-c) / 16 \\
& \pi_{P}^{*}=\left(q^{*}-c\right) x^{*}=(E \tilde{\alpha}-c)^{2} / 8
\end{aligned}
$$

各均衡利潤より系列内の期待余剰 $E\left[P S^{*}\right]=3(E \tilde{\alpha}-c)^{2} / 16$, また均衡産出量より期待消費者余 剰 $E\left[C S^{*}\right]=(E \tilde{\alpha}-c)^{2} / 32$ が得られる。さらに, 系列内の期待余剰と消費者余剰の総和である 総余娂は $E\left[T S^{*}\right]=(E \tilde{\alpha}-c)^{2}(7 / 32)$ となる。

(2) 需要条件を把握する販売者が介在する場合の各均衡諸量は, 前節で求めた通りである。

(3) 販売者が生産者に情報を伝達する場合は, 両者共に市場に対応し, 各均衡利潤が $\tilde{\alpha}$ の関数 になる。販売者の利潤関数 $\pi_{D}=(\tilde{\alpha}-x-q) x$ が得られ，利潤極大化の第 1 次条件より，反応関 数は $x=(\tilde{\alpha}-q) / 2 \equiv \phi(q \mid \tilde{\alpha})$ となる。生産者の利潤関数は $\pi_{P}=(q-c) \phi(q \mid \tilde{\alpha})$ によって与え られるから, 生産者は, 販売者の反応関数を考慮した利潤 $\pi_{P}=(q-c)(\tilde{\alpha}-q) / 2$ の最大化を図 る。このとき, 均衡卸売価格は $q^{*}=(\tilde{\alpha}+c) / 2$ となり，このとき，反応関数に代入すると，販 売者の仕入れ量が $x^{*}=(\tilde{\alpha}-c) / 4$ に定まる。これより生産者の期待利潤 $E\left[\pi_{P}^{*}\right]=(E \tilde{\alpha}-c)^{2} / 8$ + Var $\tilde{\alpha} / 8$ が得られる。注意すべさことには, 生産者が実現值を知り得ないときには均衡卸売 価格は確定值となるが, 情報を獲得すれば, それは需要の実現值に対応した $\tilde{\alpha}$ の関数になる。つ まり，無知の生産者は固定的な行動（routine action）を採択するが，販売者から情報を得た生 産者は需要動向に連結させ卸売価格を決定する。販売者の利潤関数も $\tilde{a}$ の関数になり,

$$
\pi_{D}^{*}=\left(\tilde{\alpha}-x^{*}-q^{*}\right) x^{*}=(\tilde{\alpha}-c)^{2} / 16
$$


となる。上式の期待值は $E\left[\pi_{D}^{*}\right]=(E \tilde{\alpha}-c)^{2} / 16+\operatorname{Var} \tilde{\alpha} / 16$ となり，系列内の期待余剰 $E\left[P S^{*}\right]$ $=\left\{(E \tilde{\alpha}-c)^{2}+\operatorname{Var} \tilde{\alpha}\right\}(3 / 16)$ が得られる。また, 均衡産出量 $x^{*}$ 需要関数に代入し市場価格 $p^{*}$ を求めると, 期待消費者余剩 $E\left[C S^{*}\right]=\left\{(E \tilde{\alpha}-c)^{2}+\operatorname{Var} \tilde{\alpha}\right\} / 32$ と期待総余剰 $E\left[T S^{*}\right]=$ $\left\{(E \tilde{\alpha}-c)^{2}+\operatorname{Var} \tilde{\alpha}\right\}(7 / 32)$ が導出される。

以上の結果から, 次の定理が得られる。ただし, 販売者が介在せず生産者のみが存在する場 合の各諸量は $P$ を添え字とする（前節の結果を利用した）。また，各情報構造 (1)，(2)，(3)，の下 での各期待值には，それぞれ $O, M, S$ の添え字を付ける。

定理 1.（情報構造変化の厚生効果）

(i ) $E\left[\pi_{P}^{0}\right]=E\left[\pi_{P}^{M}\right]<E\left[\pi_{P}^{P}\right]<E\left[\pi_{P}^{s}\right](\operatorname{Var} \tilde{\alpha}$ が十分大きいとき)

(ii) $E\left[\pi_{D}^{O}\right]<E\left[\pi_{D}^{S}\right]<E\left[\pi_{D}^{M}\right](\operatorname{Var} \tilde{\alpha}>0)$ 。

(iii) $E\left[P S^{o}\right]<E\left[P S^{P}\right]<E\left[P S^{S}\right]<E\left[P S^{M}\right](\operatorname{Var} \tilde{\alpha}$ が十分大きいとき)

(iv) $E\left[C S^{o}\right]<E\left[C S^{P}\right]<E\left[C S^{S}\right]<E\left[C S^{M}\right](\operatorname{Var} \tilde{\alpha}$ が十分大きいとき)

(v) $E\left[T S^{o}\right]<E\left[T S^{P}\right]<E\left[T S^{S}\right]<E\left[T S^{M}\right](\operatorname{Var} \tilde{\alpha}$ が十分大きいとき)

この定理の（ii）〜（iv）から明らかなことは，需要不確実性が増大すれば, 情報入手の販売者 が介在することによって，社会厚生が増大するということである。思うに，販売者の介在は価 格の上乗せというマイナスの厚生効果を生むとともに, 情報効果というプラスの厚生効果をも たらす。したがって, 需要不確実性の程度が十分大きい場合には, プラスの効果がマイナスの 効果を上をわるようになり，生産者余剰，消費者余剒，および社会総余剰がすべて増大するこ とになる。

次に，販売者が生産者に情報を伝達しない場合（情報構造 $M$ ）と，情報を生産者と共有する 場合（情報構造 $S$ ）を比べてみよう。（i ）によると，情報を伝達しない販売者の介在は生産者 側に利潤低下をもたらすが，(iii）より生産者余剩が大きいので, 販売者から生産者側へのサイ ド・ペイメントにより系列形態を維持できるならば，流通業者の存在は生産者にとっても好ま しいことになる。しかし，サイド・ペイメントが発生しないならば，（ii）が示すよらに，販売 者は「情報」の占有によって最も高い期待利潤 $E\left[\pi_{D}^{M}\right]$ を獲得できるので, 生産者側に伝達する インセンティブを持たない。

\section{4. 危険回避的販売者から生産者への情報伝達}

前節では，販売者を危険中立者とみなし，期待利潤を最大化すると仮定した。だが，以下で は，この仮定をもっと現実的なものにして，販売者が危険回避的であり，(期待)効用を最大化 するとする。このとき，販売者のみが情報を入手し生産者が需要不確実性に直面しているなら 
ば，均衡卸売価格と均衡仕入れ量は次のように定式化される。

$$
\begin{aligned}
& x^{*}=\arg \max _{x \geq 0} U\left[\left(\pi_{D}\left(q^{*}, x \mid \tilde{\alpha}\right)\right] \equiv \phi\left(q^{*} \mid \tilde{\alpha}\right)\right. \\
& q^{*}=\arg \max _{q \geq 0} \underset{\tilde{\alpha}}{E}\left[\pi_{P}(q, x(\tilde{\alpha}))\right]=\arg \max _{q \geq 0} \underset{\tilde{\alpha}}{E}\left[\pi_{P}(q, \phi(q \mid \tilde{\alpha}))\right]
\end{aligned}
$$

(1) 最初に, レファレンス・ポイントとして販売者が無情報の場合を考える。ここで, 計算上 の便宜を図り, 危険回避的販売者の効果を表すにあたり絶対的危険回避一定の効用関数 $U(\pi)$ $\equiv 1-\exp [-R \cdot \pi]$ を導入する ${ }^{6)}$ 。需要条件の実現値を知り得ない販売者は期待効用を最大化す ることになり，期待効用は次の式で表される7)。

$$
\begin{aligned}
E\left[\pi_{D}\right] & =E[1-\exp [-R\{x(\tilde{\alpha}-x-q)\}]] \\
& =1-\exp \left[-R\left\{x(E \tilde{\alpha}-x-q)-R x^{2} \cdot \operatorname{Var} \tilde{\alpha} / 2\right)\right]
\end{aligned}
$$

期待効用極大化の第 1 次条件から, 所与の卸売価格に対する購入量の反応関数 $x^{*}=\left(E \tilde{\alpha}-q^{*}\right) /$ $(2+R \cdot \operatorname{Var} \tilde{\alpha}) \equiv \phi\left(q^{*}\right)$ が定まる。先導者である生産者は, この反応関数を取り込み, 自己の期 待利潤 $E\left[\pi_{P}\right]=E[(q-c) \phi(q)]$ の最大化を目指す。そのことより, $q^{*}=(E \tilde{\alpha}+c) / 2$ が得られ, 反応関数を利用すれば，生産者側の期待利潤は,

$$
E\left[\pi_{P}^{*}\right]=\left(q^{*}-c\right) x^{*}=(E \tilde{\alpha}-c)^{2} / 4(2-R \cdot \operatorname{Var} \tilde{\alpha})
$$

となる。販売者の期待効用は, (7) 式に $q^{*}, x^{*}$ を代入することにより, 以下のように求められ る。

$$
\begin{aligned}
E\left[U\left(\pi_{D}^{*}\right)\right] & =1-\exp \left[-R\left\{x^{*}\left(E \tilde{\alpha}-x^{*}-q^{*}\right)+R\left(x^{*}\right)^{2} \cdot \operatorname{Var} \tilde{\alpha} / 2\right\}\right] \\
& =1-\exp \left[\frac{-R(E \tilde{\alpha}-C)^{2}}{8(2+R \cdot \operatorname{Var} \tilde{\alpha})}\right]
\end{aligned}
$$

(2) 次に, 販売者は, 需要条件の実現値を知り得ると仮定しょう。この場合, 販売者は効用そ のものを最大化するので, 購入量は確率変数 $\tilde{\alpha}$ の関数になり, 反応関数は $x=(\tilde{\alpha}-q) / 2 \equiv \phi(q$ $\mid \tilde{\alpha})$ となる。他方, 生産者は, 反応関数の実現值を知り得ないために, 期待利潤 $E\left[\pi_{P}\right]=(q$ $-c) E[\phi(q \mid \tilde{\alpha})]$ の最大化を試みる。したがって, $q^{*}=(E \tilde{\alpha}+c) / 2$ と $x^{*}=(2 \tilde{\alpha}-E \tilde{\alpha}-c) / 4 \equiv$ $\phi\left(q^{*} \mid \tilde{\alpha}\right)$ が得られ, 生産者の期待利潤 $E\left[\pi_{P}^{*}\right]$ が次のように求められる。

6）計算すれば直ちに分かるように, $-U^{\prime \prime}(\pi) / U^{\prime}(\pi)=R$ が成立する。したがって，効用関数 $U(\pi)=1-$ $\exp [-R \cdot \pi]$ は，絶対的危険回避がつ齐に $R$ に等しい関数である。危険回避の測度之応用については, 酒井 $[12]$ が詳しい説明を与えている。

7) 式 (7), (9), (11), (12), の導出については, 次の数学定理を用いている。

定理。いま $\tilde{a}$ を正規分布 $N\left(\mu, \sigma^{2}\right)$ 飞従う確率変数とし， $k$ を定数とする。このとき，次の性質が成 立する。
(i) $E \exp [k \tilde{a}]=\exp \left[k \mu+(1 / 2) k^{2} \sigma^{2}\right]$
(ii) $\operatorname{Eexp}\left[k \tilde{a}^{2}\right]=\left(1 / \sqrt{1-2 k \sigma^{2}}\right) \exp \left[k \mu^{2} /\left(1-2 k \sigma^{2}\right)\right]$ 


$$
E\left[\pi_{P}^{*}\right]=E\left[\left(q^{*}-c\right) x^{*}\right]=(E \tilde{\alpha}-c)^{2} / 8
$$

このとき販売者の効用は, $U\left(\pi_{D}^{*}\right)=1-\exp \left[-R\left\{(2 \tilde{\alpha}-E \tilde{\alpha}-c)^{2} / 16\right\}\right]$ で表され，その期待值は 次式のように導出される。

$$
E\left[U\left(\pi_{D}^{*}\right)\right]=1-\frac{1}{\sqrt{1+R \cdot \operatorname{Var} \tilde{\alpha} / 2}} \exp \left[\frac{-R(E \tilde{\alpha}-C)^{2}}{8(2+R \cdot \operatorname{Var} \tilde{\alpha})}\right]
$$

(3)さて, 需要条件の実現值が伝達され, 生産者にこれを考慮した上で卸売価格を決定する場 合を考えてみる。生産者は確率変数 $\tilde{\alpha}$ の実現值に伝達されているので, 利潤そのものの最大化 を図る。販売者の反応関数は (2) と同様に $x \equiv \phi(q \mid \tilde{\alpha})=(\tilde{\alpha}-q) / 2$ であるから, 以前と同様にし $\tau, q^{*}=(\tilde{\alpha}+c) / 2, x^{*}=(\tilde{\alpha}-c) / 4$ となる。これらの均衡諸量を利潤関数に代入すれば, $\pi_{P}^{*}=$ $\left(q^{*}-c\right) x^{*}=(\tilde{\alpha}-c) / 8$ から期待利潤 $E\left[\pi_{P}^{*}\right]=(E \tilde{\alpha}-c)^{2} / 8+\operatorname{Var} \tilde{\alpha} / 8$ が得られる。また, 販売 者の効用は， $U\left(\pi_{D}^{*}\right)=1-\exp \left[-R\left\{(\tilde{\alpha}-c)^{2} / 16\right\}\right]$ となり，その期待値は以下のように導出され る。

$$
E\left[U\left(\pi_{D}^{*}\right)\right]=1-\frac{1}{\sqrt{1+R \cdot \operatorname{Var} \tilde{\alpha} / 8}} \exp \left[\frac{-R(E \tilde{\alpha}-C)^{2}}{2(8+R \cdot \operatorname{Var} \tilde{\alpha})}\right]
$$

以上の均衡諸量の比較をすれば，次のような定理が得られる。

定理 2.（販売者が危険回避者の場合）

(i ) $\quad E\left[\pi_{P}^{o}\right]<E\left[\pi_{P}^{M}\right]<E\left[\pi_{P}^{P}\right]<E\left[\pi_{P}^{s}\right]$

(ii-a) $\quad E\left[U\left(\pi_{D}^{o}\right)\right]<E\left[U\left(\pi_{D}^{M}\right)\right]$

(ii-b) $\quad E\left[U\left(\pi_{D}^{M}\right)\right] \lessgtr E\left[U\left(\pi_{D}^{S}\right)\right]$

$$
\Longleftrightarrow(E \tilde{\alpha}-c)^{2} \lesseqgtr \frac{4(2+R \cdot \operatorname{Var} \tilde{\alpha})(8+R \cdot \operatorname{Var} \tilde{\alpha})}{3 R^{2} \operatorname{Var} \tilde{\alpha}} \log \left[\frac{4(2+R \cdot \operatorname{Var} \tilde{\alpha})}{8+R \cdot \operatorname{Var} \tilde{\alpha}}\right]
$$

販売者の危険回避行動を仮定した定理 2 の内容は, 危険中立者である場合の前節の結果と異 なっている。以下に，要点を書いて和く。

（1）前節では危険中立的販売者を取りあげたが, そこでは生産者の期待利潤は情報の有無と関 係なく常に一定值をとった。ところが，本節のように危険回避的販売者の場合になると，生産 者側の期待利潤は販売者の情報獲得によって影響を受け, 情報量とともに大きくなってしまう。 その理由は, 危険回避的販売者が, 所与の卸売価格に対し購入量を下落させ, それが, 生産者 側の期待利潤を変化させることになるからである。しかし，販売者が生産者側に情報を伝達す るかといら点は, 販売者側の意思決定にかわり，販売者の期待効用の増減と結びついている。

（2）定理 2 の（ii-a）より，情報獲得費用が十分小さければ, 販売者には情報入手の誘因がある ことが分かる。また，定理 2 の（ii-b）から；販売者の危険回避の程度が十分大きければ, 
$E\left[U\left(\pi_{D}^{M}\right)\right]<E\left[U\left(\pi_{D}^{S}\right)\right]$ の関係が, つねに満たされ，需要動向を生産者側へ伝達することが分か る。

上で求めた定理 2 の (ii-b)を詳しく分析してみよう。均衡産出量 $x^{*}(\tilde{\alpha})$ の分散值 $\operatorname{Var}\left[x^{*}\right]$ を利用すると，情報を占有した販売者の期待効用 $E\left[U\left(\pi_{D}^{M}\right)\right]$ と，情報を共有したときの期待効 用 $E\left[U\left(\pi_{D}^{S}\right)\right]$ とは，以下のように表される。

$$
\begin{aligned}
E\left[U\left(\pi_{D}\right)\right] & =1-\frac{1}{\sqrt{1+R \cdot \operatorname{Var}\left[x^{*}\right] / 2}} \times \exp \left[\frac{-R(\operatorname{E\alpha }-c)^{2}}{16\left(1+R \cdot \operatorname{Var}\left[x^{*}\right] / 2\right)}\right] \\
& \equiv 1-\delta\left(\operatorname{Var}\left[x^{*}\right]\right) \times \gamma\left(\operatorname{Var}\left[x^{*}\right]\right)
\end{aligned}
$$

この式は, 均衡産出量の分散値を含む二つの項 $\delta(\cdot)$ と $\gamma(\cdot)$ から構成されている。 $\delta(\cdot)$ は $V a r$ $\left[x^{*}\right]$ の単調減少関数なので, 需要不確実性の増大に伴い, その情報獲得は販売者の効用を増大 させることになる。次の項 $\gamma(\cdot)$ は分散値 $\operatorname{Var}\left[x^{*}\right]$ の単調増加関数なので, 分散値の増大に伴い 期待効用を減少させる効果を持つ。これは販売者の効用関数の凹性を仮定したために，分散値 の増大が期待効用を下げることになるからである。従って，分散值の増加により，期待効用を 増大させる正の効果 $\delta(\cdot)$ と, 負の効果 $\gamma(\cdot)$ のつの経路が存在することになる。したがって, 正の効果 $\delta(\cdot)$ が負の効果 $\gamma(\cdot)$ を圧倒する限りに执いて, 販売者は情報伝達を行らインセン ティブを持つ。換言すれば，情報を相手に与えることは危険負担の一部を相手に与えることを 意味するから，危険回避者としての販売者は，生産者への情報伝達によって，むしろ利益を得 る可能性が生まれるわけである。

販売者の情報伝達が，その期待効用に及ぼす効果を図示すれば，図 1 の通りである。横軸は

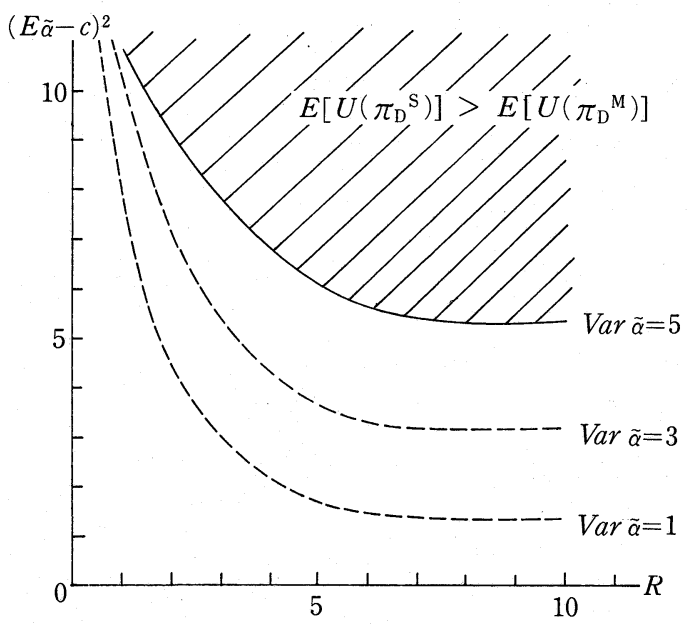

図 1 情報伝達と販売者の期待効用 
危険回避度 $R$, 縦軸は $(E \tilde{\alpha}-c)^{2}$ を測る。 $\tilde{\alpha}$ の $\operatorname{Var}[\tilde{\alpha}]$ にいては, パラメトリックに $1,3,5$ と 3 つの值をとる場合を考㝋ている。もし $\operatorname{Var}[\tilde{\alpha}]=5$ であれば，右上方の斜線部分に拈いて， 販売者の情報伝達がその期待効用を増大させる。この図が示すように, 需要の平均値や分散値 が大きければ大きいほど, 情報伝達が危険負担の分散を通じて発信者（つまり販売者）の厚生 に寄与するところが大きくなる。つまり，そのときには販売者は情報伝達のインセンティブを 持つ。さらに, このインセンティブは危険回避度 $R$ の值にも敏感であることが, 図 1 から了解 でさよう。

\section{5. おわりに}

本稿で得られた結果を簡単にまとめてみると，つぎのようである。

1）生産者の及が存在する場合と, 販売者が介在する場合を比べると, 各余剰の大小関係は, 需要不確実性の程度によって異なる。不確実性の程度が極めて弱い市場では，消費者は割高な 商品を手にする。しかし, 需要不確実性の程度が強く, 「地の利」を持つ販売者が需要動向を把 握する場合には事情が一変する。すなわち，不確実性の程度が増加するに伴い消費者余剰は増 大し，さらに系列内の余剰ないしは社会全体の厚生に関してさえも，中間業者の介在が好まし いものとなりらる。しかし， この場合，危険中立的販売者は情報を隠蔽する誘因があることに 注意すべきである。

2）販売者が危険回避者であると仮定すると，その結果は上とかなり異なる。販売者は情報 を伝達する誘因を持つ可能性が生まれる。これは, 「情報伝達」によるリスク負担効果が発生す るからである。危険回避的販売者は，「情報占有」か「情報伝達」かといら選択を迫られる。そ して，一定の条件が満たされたときに，販売者は自ら生産者側へと情報を伝達し，生産者側は 販売者介在の恩恵に浴することになる。

3）本稿では，「地の利」がない生産者側の情報収集コストが十分高いことを暗黙裏に仮定し ている ${ }^{8)}$ 。したがって，この費用の大きな変化は異なった結果を発生させることになり，昨今の 通信・情報処理技術の革新は地域間流通活動に大きな影響を及ぼすことになる。この点で，本 稿の分析は基本的には理論的分析ではあるが，地域学研究の進展のための基礎を提供すると考 えられる。

本稿で用いたモデルは, 3 つの点で制約を受けている。第 1 には, 逆需要関数の線形性の仮定 である。第 2 の制約は, 不確実性を需要曲線の平行シフトのみに求めている点である。第 3 に,

8）本稿のモデルでは, 簡単化のため, 情報収集コストの存在を敢光て明示しなかった。仮に販売者の情報収 集コストを $c_{D}$, 生産者のそれを $c_{P}$ とすれば, 各々の利潤関数は $I I_{D}=\pi_{D}-c_{D}, I I_{P}=\pi_{P}-c_{P}$ となる。この とき $c_{P}$ が $c_{D}$ よりも十分大きいと, 本文で導出した結果が同様に得られる。 
流通業者を先導者と考えるモデルが分析されていない。第 4 に, 通信情報処理技術の技術進歩 が流通活動の空間的变化に及ぼす影響が明示的に分析されていない。これらのことを十分考慮 した分析が，今後に残された課題である。

\section{参考文 献}

[ 1 ] Albaek, S., "Stackelberg Leadership as a Natural Solution under Cost Uncertainty," Journal of Industrial Economics, Vol. 38, 1990, pp. 335-347.

[2] Basar, T. and Y. Ho, "Informational Properties of the Nash Solution of the Two Stochastic Nonzero-Sum Games," Journal of Economic Theory, Vol. 7, 1974, pp. 370-384.

[3] Coughlan, A.T., "Competition and Cooperation in Marketing Channel Choice: Theory and Application," Marketing Science, Vol. 4, 1985, pp. 110-129.

[4] Etgar, M., "The Effects of Forward Vertical Integration on Service Performance of a Distributive Industry," Journal of Industrial Economics, Vol. 26, 1978, pp. 249-255.

[ 5 ] Gal-Or, E., "First Mover Disadvantages with Private Information," Review of Economic Studies, Vol. 54, 1987, pp. 279-292.

[ 6 ] Grossman, S.J. and J.E. Stiglitz, "On the Impossibility of Informationally Efficient Markets," American Economic Review, Vol. 70, 1980, pp. 393-408.

[ 7 ] Lim, C., "Risk Pooling and Intermediate Trading Agents," Canadian Journal of Economics, Vol. 14, 1981, pp. 261-275.

[8］丸山雅祥,『流通の経済分析一一情報と取引一-』, 創文社, 1988 年.

[9] McGuire, T.W. and R. Staelin, "An Industry Equilibrium Analysis of Downstream Vertical Integration," Marketing Science, Vol. 2, 1983, pp. 161-191.

[10] Newbery, D.M.G. and J.E. Stiglitz, "Pareto Inferior Trade," Review of Economic Studies, Vol. 51, 1984, pp. 1-12.

[11] Ponnsard, J.P., "Strategic Role of Information in Demand Function in an Oligopolistic Market," Management Science, Vol. 25, 1979, pp. 240-250.

[12］酒井泰弘, 『不確実性の経済学』, 有斐閣, 1982 年.

[13] Sakai, Y., "The Role of Information in a Stackelberg-Type Duopolistic Market: A linear Case," mimeo., 1984, Institute of Social Sciences, University of Tsukuba.

[14] 酒井泰弘,『葟占と情報の理論』, 東洋経済新報社, 1990 年.

[15] Sakai, Y. and A. Yoshizumi, "The Impact of Risk Aversion on Information Transmission between Firms," Zeitschrift für Nationalökonomie, Vol. 53, 1991, pp. 51-73.

[16] Sakai, Y. and A. Yoshizumi, "Risk Aversion and Duopoly: Is Information Exchange Always Beneficial to Firms?," Pure Mathematics and Applications, Vol. 2, 1992, pp. 129-145. 


\title{
Demand Uncertainty and Distribution Systems :
}

\author{
The Role of Intermediaries in the Market Economy
}

\author{
Yasuhiro SAKAI* and Keisuke SASAKI*
}

People often call distribution the "Dark Continent" of the economy. Most conventional models have difficultly of exploring the working and performance of distributors, i.e., a sequence of intermediaries which connect producers with consumers. We have yet to adopt a new approach to distributive intermediation. The main purpose of this paper is to investigate the informational role of intermediaries in the market economy, thus shedding new light on the Dark Continent.

In the ideal world of certainty, producers and consumers may meet each other face to face, causing no frictions throughout trading. The presence of distributors would merely serve as a complication factor for the linkage between producers and.consumers. Indeed, we can show that when distributors enter as middlemen, output decreases and consumer price rises, whence social welfare declines.

The question to ask is how the presence of demand uncertainty changes the welfare results obtained for the world of certainty. In order to emphasize informational asymmetry, we assume that the distributor is fully informed about demand but the producer is not so informed. Then we can see that whenever the uncertainty is large, the entry of the informed distributor increases social welfare. However, the risk neutral distributor has no incentive to reveal private information to the producer.

If the distributor displays risk aversion and maximizes the expected utility of profit rather than the expected profit per se, then the situation must change completely. It is due to fact that in the case of risk aversion, information sharing implies the sharing of risk-bearing as well through its effect on the variance of the profit. Consequently, if the uncertainty is large enough, the risk-averse distributor may wish to share the information with the producer.

To sum up, whenever demand uncertainty is present and the distributor has a significant advantage over the producer in collecting the information, the economy with distribution channels is socially more desirable than the one without. Moreover, if the distributor exhibits strong risk aversion, then he wishes to share the information with the producer. Further research on this area should be awaited.

\footnotetext{
* Institute of Social Sciences, University of Tsukuba.
} 